\title{
APOSISI PADA TEKS BERITA UTAMA JAWA POS
}

\author{
Dian Anik Cahyana
}

\author{
diananik.stkipjb@gmail.com \\ Universitas Sebelas Maret \\ Surakarta, Jawa Tengah, Indoesia
}

\begin{abstract}
Aposisi merupakan satuan lingual berkategori benda yang berfungsi untuk menjelaskan atau mencirikan elemen yang lain. Aposisi bisa terletak di depan atau di belakang elemen inti, selama elemen tersebut dapat mendukung elemen lain dalam kalimat serta memberikan informasi yang sesuai dan berkaitan dengan yang lain. Tulisan ini bertujuan untuk mendeskripsikan jenis dan penggunaan aposisi didalam teks berita, khususnya aposisi yang terdapat di koran Jawa Pos. Sumber data dalam tulisan ini diambil dari koran Jawa Pos edisi bulan November 2016, yang berupa berita utama. Dari hasil temuan, jenis aposisi yang ditemukan adalah aposisi pembatas (restriktif). Aposisi jenis ini merupakan pronomina yang menyangkut identitas, Pronomina tersebut hanya mengaju pada satu orang (tunggal). Sedangkan tujuan penggunaan aposisi khususnya pada teks berita yaitu: memberikan Edukasi Informasi baru kepada masyarakat khususnya pembaca, membangun Citra Tokoh, pencitraan tokoh tersebut bisa baik atau buruk, Kompetisi Bahasa dan Ketercukupan Informasi, membangun pemahaman pembaca dengan menghadirkan informasi yang cukup atau kehadiran aposisi lebih dari satu.
\end{abstract}

Keywords: Aposisi, teks berita, koran, Jawa Pos

\section{PENDAHULUAN}

Informasi merupakan pesan atau kumpulan pesan yang penting dalam kehidupanmanusia. Agar pesan sampai kepada yang menerima pesan tersebut, pengirim pesan harus memberikan informasi yang jelas dan akurat. Dalam hal ini aposisi memberikan informasi spesifik yang bisa muncul dalam konteksnya yang berfungsi untuk menambahkan informasi, sehingga aposisi memberikan informasi tambahan yang berguna untuk menyampaikan pesan lebih rinci, yang membuat penerima pesan mengerti pesan yang disampaikan. Aposisi tidak hanya berfungsi sebagai alat komunikasi tetapi aposisi juga berguna untuk pembaca memahami sebuah teks bacaan.

Aposisi merupakan satuan lingual berkategori benda yang berfungsi untuk menjelaskan atau mencirikan elemen yang lain. Aposisi bisa terletak di depan atau di belakang elemen inti, selama elemen tersebut dapat mendukung elemen lain dalam kalimat serta memberikan informasi yang sesuai dan berkaitan dengan yang lain. Tulisan ini bertujuan untuk mendeskripsikan jenis dan penggunaan aposisi didalam teks berita utama, khususnya teks berita yang terdapat di koran Jawa Pos.

Penelitian terkait aposisi pernah dilakukan oleh Dany Ardhian yang berjudul Aposisi Bahasa Indonesia tahun 2013. Penelitian ini mengangkat tentang penggunaan aposisi pada praktek jurnalisme pers pada koran Kompas edisi bulan Oktober 2011.

\section{KAJIAN TEORI Aposisi}

Satuan lingual berkategori benda yang berfungsi menjelaskan atau mencirikan yang lain yang ditempatkan di sampingnya (bersebelahan), konstruksi itu disebut aposisi (Curme, 1947, h. 129). Aposisi juga menjadi 
pelengkap pada satuan lingual benda yang mengekspresikan kata benda tersebut (Paladian, 2003).

Aposisi merupakan konstruksi gramatikal yang melibatkan dua frasa benda yang saling bertalian, salah satunya mendefinisikan atau memodifikasi yang lain (Favre dan Dilek, 2009, h. 2771). Jika terdapat elemen yang berdekatan dan tidak memiliki perbedaan referen, hubungan tesebut merupakan aposisi (Matthews, 1997, h. 22). Aposisi itu menyangkut identitas (Verhaar, 2010, h. 306).

Sedangkan ciri aposisi, apakah hanya terletak berimpitan atau tidak serta apakah hanya hasil permutasian dan pelesapan yang menghasikan kalimat gramatikal saja yang bisa disebut aposisi. Posisi aposisi tidak bisa ditetapkan dengan pasti apakah di depan ataukah di belakang. Pada kenyataannya, peran semanrik memutuskan posisi dan konsekuensinya tentang aposisi yang mana yang menjadi suplemen informasi buat elemen lainnya.

Aposisi dapat di depan atau di belakang. Elemen-elemen yang diprediksi aposisi dapat ditempatkan atau diakui aposisi setelah elemen tersebut mendukung elemen yang lain dalam kalimat. Jika elemen satu mampu memberikan metadiskurs (informasi sesuai dan berkaitan) pada elemen yang lain, maka elemen tersebut merupakan aposisi (Paladian: 2003).

Berdasarkan uraian diatas dapat disimpulkan bahwa aposisi bisa terletak di depan atau di belakang elemen inti. Selama elemen tersebut dapat mendukung elemen lain dalam kalimat, serta memberikan informasi yang sesuai dan berkaitan pada elemen yang lain. Aposisi bisa terjadi lebih dari satu elemen di belakang elemen inti, dan aposisi bisa terjadi pada pemberian informasi yang lebih spesifik atau mungkin lebih umum dari elemen intinya.

\section{Jenis-Jenis Aposisi}

Berkaitan dengan hal tersebut, Quirk (1985, h. 300) menyebutkan jenis-jenis aposisiyaitu: aposisi penuh (full), aposisi sebagian (partial), aposisi kuat (strict), aposisi lemah (weak), aposisi terbatas (restrictive) dan apposisi takterbatas (nonrestrictive); aposisi non-restriktif di pisahkan tanda baca seperti koma atau tanda baca lainnya.

\section{Fungsi Aposisi}

Ada beberapa fungsi aposisi menurut Ardhian (2013, h. 58) yaitu:

Edukasi Informasi; dalam rangka mendidik pembaca, informasi-informasi yang baru serta relevan dan penting perlu untuk disuguhkan. Hal ini sejalan dengan pendapat Juwito (2008, h. 33) yang menyatakan apapun informasi yang disebarluaskan pers hendaknya dalam kerangka mendidik (to educate).

Pembangunan Citra Tokoh; bahasa jurnalistik dapat menimbulkan citra tertentu pada sesuatu yang diberitakan. Dengan menggunakan diksi tertentu, turut berperanserta dalam membentuk sebuah citra tokoh. Pencitraan tokoh dalam informasi yang diberikan kepada masyarakat, bisa membangun citra yang baik ataupun buruk.

Kompetisi Bahasa; bahasa jurnalistik selalu menggunakan ragam formal. Ragam formal yang dimaksud adalah penggunaan bahasa resmi suatu Negara. Pada berita tertentu, ragam bahasa lain seperti bahasa asing, register, atau bahasa slank digunakan dalam peristiwa sebenarnya sehingga jurnalistik yang berpedoman pada ragam resmi cenderung mengompetisikan istilah tertentu.

Ketercukupan Informasi; aposisi hierarkial merupakan aposisi yang kemunculannya disebabkan oleh informasi yang diberikan bersifat integral. Sehingga kehadiran atau munculnya aposisi dalam sebuah wacana bisa muncul lebih dari satu.Hal ini dikarenakan satu aposisi kurang begitu memberi kelengkapan informasi sehingga memerlukan aposisi-aposisi lainnya untuk memperjelas suatu informasi.

\section{Teks Berita}

Teks berita merupakan suatu teks yang berisikan informasi mengenai suatu hal atau kejadian yang terjadi dan masih hangat diperbincangkan oleh banyak orang. Teks berita biasanya disiarkan melalui media elektronik atau media cetak seperti koran dan majalah. Dengan membaca teks berita dapat memperoleh informasi mengenai suatu hal yang dapat menambah wawasan sehingga dapat berfikir secara kreatif, efektif dan kritis terhadap suatu masalah.

Charnley (1975, h. 44) berita adalah laporan yang tepat waktu mengenai fakta atau 
opini yang memiliki daya tarik atau hal penting bagi masyarakat luas. Berita bagi suatu surat kabar adalah keterangan mengenai peristiwa atau isi pernyataan yang perlu bagi pembacanya untuk mewujudkan filsafat hidupnya.

Berita merupakan suatu fakta atau ide atau opini aktual yang menarik dan akurat serta diangap penting bagi sejumlah besar pembaca, pendengar maupun penonton.

Suatu peristiwa bisa disebut berita apabila sudah disiarkan, dilaporkan, atau diinformasikan. Berita dalam media cetak dapat dilihat pada surat kabar, tabloid, atau majalah. Di dalam berita, selalu terdapat informasi. Kita dapat mengetahui informasi tersebut dengan berpegang unsur-unsur berita.

Unsur - unsur berita yaitu 5W $1 \mathrm{H}$ yang meliputi: what (apa yang terjadi di dalam suatu peristiwa), who (siapa yang terlibat di dalamnya), where (di mana terjadinya peristiwa itu), when (kapan terjadinya), why (mengapa peristiea itu terjadi), how( bagaimana terjadinya).

\section{Jawa Pos}

Jawa Pos merupakan salah satu surat kabar harian yang berpusat di Surabaya, Jawa Timur. Jawa Pos merupakan harian terbesar di Jawa Timur, dan merupakan salah satu harian dengan oplah terbesar di Indonesia. Jawa Pos, berisi berita-berita utama, politik, ekonomi/bisnis, Jawa Timur, nasional, internasional, dan rubrik-rubrik tematik lainnya.

Sebagai salah satu surat kabar harian nasional, Jawa Pos menggunakan ragam bahasa. Ragam bahasa tersebut disebut sebagai ragam bahasa jurnalistik, dimana ragam bahasa jurnalistik harus tunduk kepada kaidah danetika bahasa baku. Ciri utama bahasa jurnalistik diantaranya adalah: sederhana, singkat, padat, lugas, jelas, jernih, menarik, demokratis, mengutamakan kalimat aktif, sejauh mungkin menghindari penggunaan kata atau istilah - istilah teknis, dan tunduk kepada kaidah serta etika bahasa baku (Juwito, 2008, h. 38).

Berkaitan dengan data penelitian yang diambil dari teks berita, Charnley (dalam Juwito: 2008) berpendapat bahwa berita merupakan laporan tercepat dari suatu peristiwa atau kejadian yang factual, penting, dan menarik bagi sebagian besar pembaca. Berita selalu memperhatikan unsur-unsur produksinya yaitu $5 \mathrm{~W}+1 \mathrm{H}$ agar berita tersebut lengkap, akurat, serta memenuhi standar teknis jurnalistik.

\section{METODE}

Penelitian ini dilakukan pada surat kabar harian Jawa Pos edisi bulan November 2016. Tujuan dari penelitian ini adalah untuk mengetahui motif penggunaan aposisi dalam teks berita. Pengambilan data berdasarkan sample bertujuan (purposive sampling) (Moleong, 2010, h. 223). Sedangkan sumber datanya berupa berita utama, teknik analisis data menggunakan analisis konten, simak serta catat. Peneliti juga menginterpretasikan data berdasarkan tujuan penelitian.

\section{PEMBAHASAN}

Pada bagian hasil dan pembahasan ini akan mendeskripsikan hal-hal yang melatarbelakangi penggunaan aposisi khususnya pada teks berita yang terdapat di Koran Jawa Pos.

\section{A. Edukasi Informasi}

Dalam rangka mendidik pembaca, informasi-informasi yang baru serta relevan dan penting perlu untuk disuguhkan. Hal ini sejalan dengan pendapat Juwito (2008, h. 33) yang menyatakan apa pun informasi yang disebarluaskan pers hendaknya dalam kerangka mendidik (to educate).

Sejalan dengan pendapat di atas, maka dibawah ini disajikan data serta analisis yang berkaitan dengan Edukasi Informasi:

(1) Presiden Joko Widodo (Jokowi) tidak menghalangi rencana aksi massa pada 4 November. Hanya, dia mengingatkan agar demonstrasi tersebut tidak melampaui batas. (1 Nov 2016)

(2) Kemarin Jokowi menemui Ketua Umum Partai Gerindra Prabowo Subianto di Hambalang, Bogor. (1 Nov 2016)

(3) Sementara itu, Kapolri Jendral Tito Karnavian menegaskan bahwa ada beberapa prinsip yang tidak boleh dilanggar dalam demonstrasi atau penyampaian pendapat. (1 Nov 2016)

(4) Kapolri menegaskan, tidak ada perintah tembak di tempat. Sebelumnya, isu itu mencuat terkait dengan pernyataan Kapolda Metro 
Jaya Irjen Mochamad Iriawan. (1 Nov 2016)

(5) Kapolri mengatakan bahwa pihaknya sedang memproses kasus dugaan penistaan agama yang dilakukan oleh Gubernur DKI Jakarta Basuki Tjahaja Purnama alias Ahok. (1 Nov 2016)

Pada data (1) sampai dengan data (5) merupakan informasi yang umum. Frasa Presiden Joko Widodo (Jokowi), Ketua Umum Partai Gerindra Prabowo Subianto, Kapolri Jendral Tito Karnavian, Kapolda Metro Jaya Irjen Mochamad Iriawan, Gubernur DKI Jakarta Basuki Tjahaja Purnama alias Ahok, merupakan pronomina yang menyangkut identitas, sehingga aposisi ini termasuk aposisi pembatas (restriktif). Pronomina tersebut hanya mengaju pada satu orang (tunggal), informasi yang diberikan kepada masyarakat kurang detail sehingga aspek ketercukupan informasi sebagai bentuk edukasi masyarakat menjadi berkurang. Karena informasi edukasi yang diberikan kepada masyarakat berkurang, sehingga dimunculkan aposisi sebagai unit kedua untuk memastikan pronominal yang dirujuk. Pada data (1) yaitu Joko Widodo (Jokowi), data (2) yaitu Prabowo Subianto, data (3) yaitu Jenderal Tito Karnavian, data (4) Irjen Mochamad Iriawan, dan data (5)Basuki Tjahaja Purnama alias Ahok.

Dari data di atas, apabila unit yang kedua dihilangkan Uoko Widodo, Prabowo Subianto, Jenderal Tito Karnavian, Irjen Mochamad Iriawan, dan Basuki Tjahaja Purnama alias Ahok), maka informasi yang diberikan kepada masyarakat menjadi tidak lengkap. Karena tidak semua masyarakat khususnya di Indonesia mengenal siapa itu Joko Widodo, Prabowo Subianto, Jenderal Tito Karnavian, Irjen Mochamad Iriawan, serta Basuki Tjahaja Purnama alias Ahok, sehingga akan mengalami kekurangan informasi dalam memahami sebuah wacana.

Kehadiran aposisi dalam data (1) sampai dengan data (5), secara langsung turut memberikan informasi terhadap pembaca sehingga pembaca mendapatkan informasi baru atau pembenaran informasi sebelumnya. Kehadiran aposis sangatlah penting untuk memandu pembaca sehingga pembaca tidak merasa bingung dalam memahami sebuah wacana dengan adanya informasi-informasi baru.

\section{B. Pembangunan Citra Tokoh}

Bahasa jurnalistik dapat menimbulkan citra tertentu pada sesuatu yang diberitakan. Dengan menggunakan diksi tertentu, turut berperanserta dalam membentuk sebuah citra tokoh. Pencitraan tokoh dalam informasi yang diberikan kepada masyarakat, bisa membangun citra yang baik ataupun buruk.

Dibawah ini disajikan data serta analisis yang berkaitan dengan Pencitraan Tokoh:

(6) Kekhawatiran sejumlah kalangan akan kondisi kesehatan Dahlan Iskan, lantaran ditahan di dalam penjara akhirnya menjadi pertimbangan penyidik. Status penahanan mantan menteri BUMN itu tadi malam dialihkan menjadi tahanan kota. (1 Nov 2016)

(7) Menurut Bhaskoro, Dahlan adalah mantan menteri BUMN, tapi diperlakukan seperti itu oleh kejaksaan yang terkesan mencari cari kesalahan. Dia menegaskan, Kejaksaan Agung perlu direformasi. (2 Nov 2016)

(8) Menurut dia, penahanan Dahlan juga layak dikritik. Sebab, belum ada audit resmi terkait dengan kerugian Negara yang dikeluarkan Badan Pengawasan Keuangan dan Pembangunan (BPKP) atau Badan Pemeriksa Keuangan (BPK). (2 Nov 2016)

(9) Wakil ketua umum Partai Gerindra itu juga menyebutkan sosok Kepala Kejati Jatim Maruli Hutagalung, yang tidak bebas dari masalah. Hal tersebut terkait dengan dugaan keterlibatan Maruli dalam kasus korupsi dana bansos yang menjerat mantan Gubernur Sumatera Utara Gatot Pujo Nugroho. "Saya pikir, itu juga harus diungkap dan dituntaskan secara hokum,"tandasnya. (2 Nov 2016)

Data (6), (7) dan (8) menandakan bahwa kehadiran aposisi turut membangun citra diri seorang tokoh. Pemilihan diksi dalam memberikan suatu informasi akan mempengaruhi serta membentuk opini publik seorang tokoh. Pada data (6) menggunakan pilihan kata ditahan daripada dibui. Pada data 
(6) dan (8), penulis bermaksud untuk memperburuk citra seorang tokoh (Dahlan Iskan) dengan memunculkan aposisi relative penahanan dan lantaran ditahan di dalam penjara. Pilihan kata serta klausa relative yang menjadi aposisi secara langsung membangun citra buruk tokoh yang diberitakan / diinformasikan.

Lain halnya dengan data (6) dan (8), pada data (7) penulis memunculkan aposisi relative Dahlan adalah mantan menteri $B U M N . P i l i h a n$ kata serta klausa relative yang menjadi aposisi secara langsung membangun citra baik tokoh yang diberitakan atau diinformasikan.

Pada data (9), penulis bermaksud untuk memperburuk citra seseorang (Maruli Hutagalung) dengan cara memunculkan aposisi relativeKepala Kejati Jatim Maruli Hutagalung, yang tidak bebas dari masalah. Hal tersebut terkait dengan dugaan keterlibatan Maruli dalam kasus korupsi dana bansos. Pilihan klausa relative yang menjadi aposisi ini secara langsung membangun citra buruk tokoh yang diberitakan atau diinformasikan kepada masyarakat.

\section{Kompetisi Bahasa}

Bahasa jurnalistik selalu menggunakan ragam formal. Ragam formal yang dimaksud adalah penggunaan bahasa resmi suatu Negara. Pada berita tertentu, ragam bahasa laian seperti bahasa asing, register, atau bahasa slank digunakan dalam peristiwa sebenarnya sehingga jurnalistik yang berpedoman pada ragam resmi cenderung mengompetisikan istilah tertentu.

Dibawah ini disajikan data serta analisis yang berkaitan dengan Kompetisi Bahasa:

(10) Sudah 15 saksi yang diperiksa. Termasuk Ahok dan kubu Front Pembela Islam (FPI). (1 Nov 2016)

(11) Kemarin RI-1 itu mengundang para ulama untuk membahas ancaman kekerasan dalam unjuk rasa tersebut. Yang diundang antara lain adalah ketua Majelis Ulama Indonesia (MUI). Juga perwakilan dua ormas terbesar Indonesia, Nahdlatul Ulama (NU) dan Muhammadiyah. (2 Nov 2016)

(12) Sementara itu, potensi kerusuhan pada demo Jum'at lusa tersebut, salah satunya, disebarkan dari media sosial (medsos). (1 Nov 2016)

(13) Termasuk tanggal 4 November ini mereka ambil kesempatan untuk sebarkan paham mereka, rasa kebencian yang sama terhadap yang bukan Islam, tambah mantan amir mantiqi Jamaah Islamiyah (JI). JI salah satu jaringan teroris yang pernah melancarkan terror di Indonesia. (2 Nov 2016)

(14) Menurut dia, penahanan Dahlan juga layak dikritik. Sebab, belum ada audit resmi terkait dengan kerugian Negara yang dikeluarkan Badan Pengawasan Keuangandan Pembangunan (BPKP) atau Badan Pemeriksa Keuangan (BPK). (2 Nov 2016)

Pada data (10), unit pertama dan kedua merupakan padanan satuan lingual. Munculnya bentuk padanan (sinonim) dari bahasa yang berbeda akan menimbulkan kompetisi bahasa, dalam hal ini adalah kompetisi istlah. Istilah sinonim yang digunakan di sini mengandung generalisasi.Istilah sinonim tidak serta merta bermakna sesungguhnya dalam tataran semantik, tetapi lebih bermakna pada pengertian yang terfokus kepada maksud penutur atau pembaca. Istilah sinonim dalam konteks ini adalah sebuah penjelasan atau klarifikasi suatu makna. Satuan lingual frasaFront Pembela Islamdijelaskan, bahkan diklarifikasi kebenarannya dengan FPI.

Begitu juga dengan satuan lingual frasa pada data (11) Majelis Ulama Indonesiadijelaskan, bahkan diklarifikasi kebenarannya dengan $M U I$, serta Organisasi Masyarakat dijelaskan denganormas, dan Satuan lingual frasa Nahdlatul Ulama dijelaskan serta diklarifikasi dengan NU.

Tidak jauh berbeda dengan data sebelumnya, data (12), (13) dan data (14), dengan satuan lingual frasa pada data (12) media sosial, data (13) amir mantiqi Jamaah Islamiyah, dan data (14) Badan Pengawasan Keuangandan Pembangunan atau Badan Pemeriksa Keuanganpenulis memberi penjelasan yang lebih universal bahkan diklarifikasikan kebenarannya dengan istilah medsos, JI, BPKP atau BPK.

Munculnya aposisi baik FPI, MUI, Ormas, $N U$, medsos, JI, BPKP atau BPK, yang 
disandingkan dengan leksikalnya terlihat bertujuan untuk mengompetisikan satuan lingualnya. FPI, MUI, Ormas, $N U$, medsos, $J I$, $B P K P$ atau $B P K$ sudah lebih dulu terkenal di masyarakat dari pada satuan lingual Front Pembela Islam, Majelis Ulama Indonesia, Organisasi Masyarakat, Nahdlatul Ulama, media sosial, Jamaah Islamiyah, Badan Pengawasan Keuangandan Pembangunan atau Badan Pemeriksa Keuangan.

\section{Ketercukupan Informasi}

Aposisi hierarkial merupakan aposisi yang kemunculannya disebabkan oleh informasi yang diberikan bersifat integral. Sehingga kehadiran atau munculnya aposisi dalam sebuah wacana bisa muncul lebih dari satu.Hal ini dikarenakan satu aposisi kurang begitu memberi kelengkapan informasi sehingga memerlukan aposisi-aposisi lainnya untuk memperjelas suatu informasi.

Dibawah ini disajikan data- data yang termasuk Ketercukupan Informasi:

(15) Kemarin Jokowi menemui Ketua Umum Partai Gerindra Prabowo Subianto di Hambalang, Bogor. (1 Nov 2016)

(16) Meski begitu, aparat keamanan harus tetap waspada. Ada kemungkinan teroris melancarkan aksi. Desain yang dibuat diperkirakan seperti kasus penembakan di kantor Charlie Hebdo di Paris, Perancis, pada Januari 2015. (1 Nov 2016)

(17) Chaidar menuturkan, ada ancaman dari Jaisyul Fath di Syria. Kelompok tersebut dikenal dekat dengan jaringan teroris Al Qaeda. Dia menduga akan ada serangan kepada orang-orang yang menistakan agama Islam. "Mereka akan menyerang Ahok dengan senjata," ujar pengajar di Departemen Antropologi FISIP Universitas Malikussaleh, Aceh, itu. (1 Nov 2016)

(18) Pengalihan itu dilakukan setelah keluarga Dahlan dan pimpinan Pesantren Sabilil Muttaqien, Takeran, Magetan, Jawa Timur mengajukan permohonan agar Dahlan dikeluarkan dari tahanan. (1 Nov 2016)

Data (15) dan (16), kehadiran aposisi kedua dan seterusnya sangat membantu pembaca dalam memahami sebuah wacana. Jika kehilangan salah satu aposisi, maka pembaca akan merasa kebingungan dalam memahami wacan tersebut. Munculnya aposisi (15) Bogor dan (16) Perancis, dari data (15) Hambalang, Bogordan (16)Charlie Hebdo di Paris, Perancis, sangatlah membantu para pembaca dalam menentukan letak peristiwa, apalagi pembaca yang tidak berasal dari daerah tempat peristiwa itu berada. Dari data (15) pembaca akan memahami bahwa letak kota Hambalang itu berada di daerah Bogor, begitupula data (16) pembaca akan memahami bahwa letak Charlie Hebdo itu berada di Paris, Perancis.

Tidak jauh berbeda dengan data (15) dan (16), data (17) dan (18) juga termasuk ketercukupan informasi karena munculnya aposisi dalam sebuah wacana lebih dari satu sehingga dapat memberikan kejelasan informasi bagi orang lain (pembaca). Pada data (17) Syiria dan Aceh, dari aposisi Jaisyul Fath di Syriadan Departemen Antropologi FISIP Universitas Malikussaleh, Aceh. Hadirnya aposisi kedua Syiria dan Aceh, sangatlah membantu para pembaca dalam menentukan letak peristiwa, apalagi pembaca yang tidak berasal dari daerah tempat peristiwa itu berada.Sehingga pembaca bisa memahami isi dari sebuah wacana seperti data (17) bahwasannya yang dimaksud penulis kelompok Jaisyul Fath itu beradadi Syria, danUniversitas Malikussaleh itu berada di Aceh.

Data (18) Pesantren Sabilil Muttaqien, Takeran, Magetan, Jawa Timur, dengan adanya aposisi teakhir Jawa Timur akan memberikan kejelasan informasi bagi pembaca tentang letak Pesantren Sabilil Muttaqien, Takeran, Magetan. Tidak semua pembaca mengetahui Kota / Kabupaten Magetan itu berada di Jawa Timur. Sehingga kehadiran aposisi Jawa Timur sangat membantu pembaca dalam menentukan letak peristiwa, apalagi pembaca yang tidak berasal dari daerah tempat peristiwa itu berada.

\section{SIMPULAN}

Berdasarkan data-data di atas, aposisi merupakan satuan lingual berkategori benda yang berfungsi untuk menjelaskan atau mencirikan elemen yang lain. Aposisi bisa terletak di depan atau di belakang elemen inti. Selama elemen tersebut dapat mendukung 
elemen lain dalam kalimat, serta memberikan informasi yang sesuai dan berkaitan pada elemen yang lain.

Dari hasil temuan diatas, tipe aposisi yang ditemukan adalah aposisi pembatas (restriktif). Aposisi jenis ini merupakan pronomina yang menyangkut identitas, Pronomina tersebut hanya mengaju pada satu orang (tunggal). Sedangkan hal-hal yang melatarbelakangi atau tujuan penggunaan aposisi khususnya pada teks berita yaitu: memberikan Edukasi Informasi baru kepada masyarakat khususnya pembaca, aposisi digunakan untuk membangun Citra Tokoh, pencitraan tokoh tersebut bisa baik atau buruk, selain itu aposisi juga digunakan dalam Kompetisi Bahasa dan Ketercukupan Informasi (membangun pemahaman pembaca dengan menghadirkan informasi yang cukup/ kehadiran aposisi lebih dari satu).

\section{DAFTAR PUSTAKA}

Ardhian, D. (2013). Aposisi Bahasa Indonesia. Transling Journal: Translation and linguistics Vol I, No I (January 2013) pp 53-64.

Charnley,M.V. (1975). Reporting Edisi III.New York:Holt-Reinhart \& Winston.

Combettes, B. (1998). Les Constructions Detachees en Francais. Paris: Ophirus.

Curme. (1947). English Grammar. New York: Barnes and Noble.

Favre, B. dan Dilek, H. (2009). Phrase and Word Level Strategies For Detecting Apposition in Speech. Brighton Berkeley: ICSASSP

Juwito. (2008). Menulis Berita dan Feature's.Surabaya: Unesa University Press.

Matthews, P.H. (1997). Syntax. Cambridge: Cambridge University Press.

Moleong, J.L. (2010). Metode Penelitian Kualitatif. Bandung: PT. Remaja Rosdakarya.

Paladian, M. (2003). Apposition Investigationes Linguisticae. Vol. X. Poznan.

Quirk, R. (1985). A Comprehensive Grammar of The English Language. London: Longman.

Verhaar, J.V. (2010). Asas-Asas Linguistik Umum. Yogyakarta: Gadjah Mada University Press. 